\title{
The Trade-off between Equity and Efficiency: Evidence from the Reform of China's Wage Policy
}

\author{
Qiong Huang ${ }^{1} \&$ Satish Chand ${ }^{1}$ \\ ${ }^{1}$ School of Business, University of New South Wales, Canberra, Australia \\ Correspondence: Qiong Huang, School of Business, University of New South Wales, Canberra, ACT2600, \\ Australia. Tel: 6-126-268-8729. E-mail: qiong.huang@student.unsw.edu.au
}

Received: June 24, 2014 Accepted: August 5, 2014 Online Published: August 25, 2014

doi:10.5539/jpl.v7n3p79

URL: http://dx.doi.org/10.5539/jpl.v7n3p79

\begin{abstract}
Over the last 35 years, China has transformed from an egalitarian society to a nation that has one of the highest income inequality in the world. The transformation is mainly due to the economic reform carried out in 1978, which abandoned egalitarianism and endeavored to build a market economy system in contemporary China. This study reviews China's wage reform in 1978 to illustrate the trade-off between efficiency and equity that the Chinese government has experienced. The emphasis of equity before 1978, although maintaining social justice, impeded efficiency and led to a common poverty across the nation. The wage reform starting from 1978 shifted the principle of wage distribution from equity to efficiency, which no doubt unleashed productivity and promoted economic development. Yet, it also caused a rise in income inequality, which became a potential threat to the stability of society. Thus, the new Chinese leadership has again reemphasized the importance of equity in wage distribution.
\end{abstract}

Keywords: wage reform, equality, efficiency, wage inequality

\section{Introduction}

Wage payment system plays an important role in the development of each country because an appropriate wage system can promote productivity and increase people's income while an inappropriate one may undermine productivity and becomes a potential source of social conflicts (Hicks, 1955). Therefore, it is essential for the government of each nation to implement a proper wage policy that helps to promote economic growth through increasing working efficiency, and achieve social justice through improving the living standard of low-income workers as well as reducing inequality in the distribution of income between various segments of society. The selection and implementation of a proper wage policy require the government to make tradeoffs between efficiency and equity, because too much emphasis on equity in the wage distribution will undermine the economic growth for not releasing productivity thoroughly. Too much emphasis on efficiency will cause social unrest or even wars as it may enlarge wage inequality. Due to contradictions between equity and efficiency, it is not easy for each government to adopt an appropriate wage system to enlarge wage gap enough to stimulate workers but also retain the wage equality at a reasonable level to avoid social instability.

China is a good case of illustrating trade-offs between efficiency and equity in wage distribution for at least three reasons. First, Chinese leaders emphasized equity since the formation of the Republic in 1949. The ideology of egalitarianism was dominated in wage determination with the aim of maintaining social stability and justice. Thus, equity remains strong within the physic of the people. Second, the reforms implemented in 1978 were intended to improve efficiency while their effects on equity were not debated. Since the 1978 economic reform, China has achieved a remarkable annual growth rate of gross domestic product (GDP) over 9.7\%, and lifted more than 600 million people out of poverty between 1981 and 2004 (World Bank, 2010). However, the unprecedented surge in productivity and prosperity has unleashed sweeping transformations of many dimensions of economic life such as inequality in China (Brandt, Ma, \& Rawski, 2014). According to a national household survey conducted by the Chinese Academy of Social Science in 2002, the highest-income quartile of households enjoys a lion's share of the national total salary and wage earnings, which is $57 \%$. Meanwhile, the bottom $25 \%$ accounts for just $6 \%$ of capital income. According to data from China Bureau of Statistics, the national income inequality, measured as Gini coefficient, has increased from 0.18 in 1978 to nearly 0.5 today. The rise in income 
inequality means that China has transformed from a nation with equal distribution of income to one that has one of the most unequal income distributions globally. The rise in income inequality has challenged the Chinese social stability and caused a sharp rise in social unrest. Data from the Chinese government show that the number of major social incidents, including riots, strikes, demonstrations, and protests had increased from 8,700 in 1993 to 74,000 in $2002(\mathrm{Ru}, \mathrm{Lu}, \& \mathrm{Li}, 2006$, p. 151). Thus, the new leadership in China has realized the importance of income inequality and, as discussed in details later, put more attention to equal distribution of income in the new round of wage reform than before.

The purpose of this study is to review the history of China's wage reform, and thus to illustrate the important role of government in wage distribution. The rest of the paper is organized as follows. Section 2 provides a theoretical analysis of the trade-off between efficiency and equity when making economic decisions. Sections 3 and 4 review China's wage policy since 1949, and illustrate the process through which China has transformed from an egalitarian country to a nation with a high level of income inequality. Section 5 presents the empirical evidence on the impact of wage reform on wage distribution, and the final section concludes with policy implications.

\section{Theory Background}

Theoretically, efficiency refers to maximizing the total size of economic pie through allocating limited economic resources reasonably, while equity refers to a fair distribution of benefits across the population. Although concepts are clear in theory, the two can hardly be separated in the actual practice of wage distribution due to an unclear understanding of the current situation of wage distribution, i.e. whether the wage distribution is efficient (equal) or not.

To understand contradictions between efficiency and equity, we rely on the indifference curve analysis in the economic theory ( e.g., Samuelson \& Nordhaus, 2001). Figure 1 presents an Edgeworth box (Arrow, Chenery, Minhas, \& Solow, 1961, p. 394) which demonstrates indifference curves (IC) for customers A and B. The combinations of commodities on an indifference curve indicates the same level of satisfaction, and an indifference curve which is further away from the original point corresponds to a higher level of satisfaction. Thus, in Figure 2, $\mathrm{IC}_{\mathrm{A}}{ }^{0}$ and $\mathrm{IC}_{\mathrm{B}}{ }^{0}$ represent lower utility (or less stratification) for customers $\mathrm{A}$ and $\mathrm{B}$, and $\mathrm{IC}_{\mathrm{A}}{ }^{2}$ and $\mathrm{IC}_{\mathrm{B}}{ }^{2}$ represent higher utility (or more stratification). $\mathrm{O}_{\mathrm{A}} \mathrm{O}_{\mathrm{B}}$ is the Contract Curve on which all combinations of products $\mathrm{X}$ and $\mathrm{Y}$ are in the Pareto Optimality situation, i.e. no one can be better off without making the other party worse off. Moving a point outside the Contract Curve such as $\mathrm{E}$ to any point on the Contract Curve such as $\mathrm{D}$ or $\mathrm{F}$ will increase efficiency. For example, a movement from $\mathrm{E}$ to $\mathrm{D}$ raises Customer B's utility (from $\mathrm{IC}_{\mathrm{B}}{ }^{0}$ to $\mathrm{IC}_{\mathrm{B}}{ }^{2}$ ) but has no effect on the utility level of Customer A (both points $\mathrm{E}$ and $\mathrm{D}$ are on $\mathrm{IC}_{\mathrm{A}}{ }^{0}$ ). Similarly, a movement from $\mathrm{E}$ to $\mathrm{F}$ will increase Customer A's satisfaction without affecting the level of satisfaction for Customer B. Therefore, in implies that if the current state of wage distribution is off the Contract Curve, a reform that moves the current state to be on the Contract Curve will increase efficiency.

However, the choice of points on the Contract Curve is an equity issue. As discussed previously, a move from point $\mathrm{E}$ (off the Contract Curve) to $\mathrm{F}$ (on the Contract Curve) will increase efficiency. Yet, this move, apparently, increases the utility of Customer A (moving from $\mathrm{IC}_{\mathrm{A}}{ }^{0}$ to $\mathrm{IC}_{\mathrm{A}}{ }^{2}$ ) more than Customer $\mathrm{B}$, which leads to an inequality distribution. That is to say, the benefit from increasing efficiency is not equally distributed between customers. To maintain social justice, the government may want to redistribute the efficiency, such as moving point $\mathrm{D}$ to $\mathrm{P}$. Yet, this enforcement will lead to inefficient because the increase of utility of customer $\mathrm{A}\left(\mathrm{IC}_{\mathrm{A}}{ }^{0}\right.$ to $\left.\mathrm{IC}_{\mathrm{A}}^{1}\right)$ is on the cost of lowering the satisfaction of customer $\mathrm{B}\left(\mathrm{IC}_{\mathrm{B}}{ }^{2}\right.$ to $\left.\mathrm{IC}_{\mathrm{B}}{ }^{1}\right)$.

The above analysis implies that, efficiency and equity, although equally valued, are unlikely to achieve simultaneously. Therefore, when determining an economic policy such as wage policy, the government has to balance between the two. In reality, the trad-eoff between efficiency and equity depends on the relative importance of the two issues in the social context. For example, in a planned equalitarian economic system, equity is more importance than efficiency due to the need for maintaining social justice. Therefore, a wage policy should be in favor of an equalitarian wage distribution. In a social-economic system, efficiency is more important than equity to promote economic growth, and thus the wage policy should focus on efficiency and enlarge wage gaps enough to stimulate workers. 


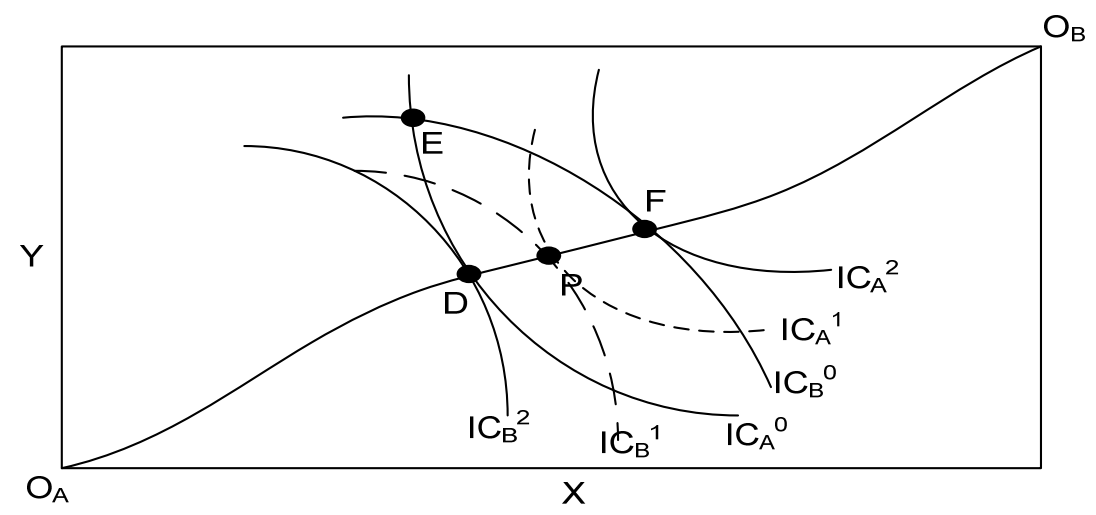

Figure 1. An Edgeworth box with issue of efficiency and equity

Source: This figure is adopted from (Sun, Zhang, \& Ge, 1989, p. 30)

\section{Wage Egalitarianism in China before 1978}

Before 1978, China adopted a planned economy system, which in general rejected the market mechanism. The establishment of a planned economy was attributed to "Socialist Transformation" between 1953 and 1957, during which the Central Government of China nationalized all private enterprises and organizations, and then transformed them into two types: state-owned enterprises (SOEs) and township and village enterprises (TVEs) (Ma, 2002). The former were managed by the Chinese Central Government directly and the latter by the local government. After completion of nationalization, a planned economic system was established, under which the government owned all enterprises and regulated workers' wages directly.

However, during the transition period from 1949 to 1956, private enterprises and state-owned enterprises coexisted. Thus, there were two wage payment systems adopted in China: one was the merchandise supply wage system (the supply system) applied in public owned enterprises and the other was the monetary wage system applied in private owned enterprises. Under the supply wage system, workers' wage were paid by the Central Government in units of commodities, such as salt, meat, and vegetables, while under monetary wage system worker were paid in cash by their employers. Nevertheless, the supply wage system was the dominant one.

The supply wage system was introduced by the Chinese Communist Party (CCP) in 1939 (Yang, 2007). This system had two noteworthy features: employees were paid in merchandises rather than currencies, and wage difference between workers were small. Under the supply wage system, workers were only divided into three types. Table 1 lists the amount of goods that the highest and lowest levels of employees received each month as salaries in Shanganning District (Note 1) between 1943 and 1949. It shows that the wage gap between workers was relatively small. For example, in 1949, the highest level and lowest level of workers received the same quantities of oil, that is 950 grams. The former received more received a larger portion of salt, meat, and coals than the latter, but less in terms of vegetables.

Table 1. The food amount for highest and lowest standard wage per employee per month at Shanganning district, 1943-1949

\begin{tabular}{cccccc|ccccc}
\hline \multirow{2}{*}{ Year } & \multicolumn{5}{c|}{ Highest Standard (Kilos) } & \multicolumn{5}{c}{ Lowest Standard (Kilos) } \\
\cline { 2 - 10 } & Oil & Salt & Meat & Vegetable & Coal & Oil & Salt & Meat & Vegetable & Coal \\
\hline 1943 & 0.75 & 0.75 & 6.4 & 19 & 21 & 0.75 & 0.75 & $0.5-1.5$ & 15 & 21 \\
1944 & 1.15 & 0.50 & $2-2.5$ & 15 & 35 & 0.75 & 0.6 & $1-1.5$ & 15 & 22.5 \\
1945 & 0.75 & 0.50 & $1.5-2$ & 15 & 22.5 & 0.5 & 0.5 & $0.5-1$ & 15 & 15 \\
1947 & 0.75 & 0.50 & 1 & 15 & 22.5 & 0.5 & 0.5 & 0.5 & 15 & 15 \\
1948 & 0.75 & 0.50 & 2.4 & 15 & 25 & 0.6 & 0.5 & $0.25-0.5$ & 11 & 20 \\
1949 & 0.95 & 0.95 & 2.4 & 18 & 30 & 0.95 & 0.75 & 0.95 & 21.5 & 20 \\
\hline
\end{tabular}

Source: Yang (2007, p. 115) Table 1 
The adoption of a supply payment system was essential in wartime because it ensured the supply of goods on the battlefield and helped the CCP to defeat the opposite party and finally won the Chinese civil war (Yang, 2007). However, after the cessation of war, this wage system became problematic. On the one hand, the equal wage system failed to motivate workers due to the relatively small wage differentials between employees. On the other hand, the workers who paid in commodities felt as being under-compensated compared with those workers who paid in currencies for not having enough money to buy other foods and commodities to improve living standards.

To solve problems mentioned above, the government abolished the supply wage system, and adopted a grade wage system following the "Socialist Transformation." In comparison with supply wage system, the grade wage system transformed of wage payment method from merchandises to currency as well as enlarged wage differentials. The grade wage system was introduced into China by experts from the former Soviet Union, and then adopted in the Northern East district of China in 1956. In this region, workers were divided into thirty-nine grades according their skills and positions. Correspondingly, there were thirty-nine levels of wages. However, because egalitarianism was still the dominated rule of wage distribution, the wage difference between workers was still relatively small before 1958. For example, the highest grade of wage was only about nine times of the lowest.

Apart from relatively small wage gaps between workers, the seniority-based and government-managed features of the grade wage system also hindered productivity. Under the grade wage system, workers' wages were strictly associated with their job positions rather than their workloads. That is, same grade of workers gained same amounts of salaries, regardless of their workloads. Moreover, the government regulated workers' wages without consideration of firms' performances. This arrangement overlooked the important role of enterprises in the wage determination, which not only distorted labor market mechanism but also hindered enterprises development. Enterprises, regardless of making profits or losses, had to pay the same level of wages to their workers. This regulation did not only add financial burdens to loss-making firms, and also created conflicts between employees and employers in profit-making firms as workers in these firms expected to receive higher salaries than those working in loss-making firms. Thus, the grade wage system, as argued by Fang (2010, p. 87), had little or even negative contribution to productivity increase and economic growth in China in the 1960s.

\section{Wage Reform after 1978: Tradeoffs between Equity and Efficiency}

In 1978, China adopted an open up policy, which is the major economic event in the history of China. The policy has fundamentally transformed the Chinese economic system from the planned economy to the market-oriented one. As an integral part of economic reform, China's wage payment system, has also undergone a series of reforms since 1978. The most fundamental transformations are the shift at the core of wage distribution from equity to efficiency and the establishment of a market-oriented wage policy. The government reformed the wage policy, on the one hand, for the need of building a market-oriented economy system. On the other hand, the government realized that the grade wage system, although it had a positive impact on achieving the aim of equity in the short run, in the long run, might led to a state of common poverty due to lack of efficiency (Sun et al., 1989) .

\subsection{Relaxing Government Regulation: 1978-1991}

Despite that the wage reform toward building a market-oriented wage system with focus on efficiency was proposed in 1978, the implementation of this reform, as reforms in other aspects, was tentative and moderate in the 1980s (Li \& Zhao, 1998). During that period, the government still put strict regulations on wages, but employees and employers were given more opportunities to participate into the process of wage decision. For example, in 1978, the government permitted enterprises to adopt a piece-rate payment system under which workers were paid based on units of output they produced. In 1983, a labor contract system was introduced to encourage workers to negotiate with employers on wages and working time. As argued by Song (2009), these reforms increased the paticipation of workers in wage decision, and promoted productivity through motivating employees to work hard to earn higher wages.

In addition, the government started to allow enterprises to adjust wages according to their economic performances. In 1983, the government abolished the prior profit-delivering system under which all firms had to hand in all profits they made to the government and then applied for funds to pay salaries, purchase materials, and meet other expenses. Instead, an income adjusted tax was introduced at the same year. The transformation from "profit-delivering" to "remaining after-tax profit" allowed firms to retain profits after paying taxes and then used these retained profits to adjust employees' wages through allowances paid. However, to avoid wage gaps between workers increasing too largely, the government restricted allowances to a maximum of three months 
salaries (Jia, 1998). Although this restriction was cancelled in 1985 (Note 2), the Chinese government still regulated that workers' wages could only fluctuate within the level of firms' economic performances.

To conclude, during the period 1978-1991, a market wage system had yet be fully established in China because the government still regulated and managed wages. However, in comparison with the grade wage system adopted in the pre-reform era, the new wage system was associated workers' wages with workload as well as enterprises' performances, which, to some extent, promoted efficiency and improved productivity (Deng, $\mathrm{Li}, \mathrm{Wu}$, $\& \mathrm{Su}, 2013)$.

\subsection{Building a Market Wage System: 1992-2002}

Another major event in the history of China's economic reform is DENG Xiaoping's Southern Tour in 1992, which marked that China entered into a rapid episode of economic reform towards a "socialist market economy." As a result, the reform of China's wage policy accelerated after 1992.

As the most important step towards building a market wage system, the government gave enterprises full autonomy in the wage decision. In 1992, at the 14th plenary meeting of the CCP (Beijing, 12-18, October, 1992), the government explicated that enterprises should have independent rights in wage determination, and the government could only provide guidelines such as regulating minimum wages and legislating protection rules for laborers. Subsequently, a series of laws and regulations were published to cut down administrative interference in wage determination. Among them, the most influential one is Company Law Art (1994), which explicitly prescribes that firms decide their employees' wages, allowances, and other welfare payments.

Moreover, efficiency replaced equity and became the main principle in wage distribution due to the shift of the national development goal from social stability to economic growth. The government realized the importance of enlarging wage gap in motivating workers and promoting efficiency. On 9 July 1995, the Chinese Labor Ministry and the State Economic and Trade commission jointly issued a regulation that guided wage reform in state-owned enterprises. It regulated that 'firms should enlarge wage gap reasonably to incentivize employees to work hard'.

These reforms mentioned above, eventually, transformed China's wage system from a state-fixed and non-performance linked to being enterprise-determined, performance-related, and incentive-oriented. Consequently, this transformation has released efficiency, promoted productivity and improved people's living standards by raising workers' wages (Zhu, De Cieri, \& Dowling, 1998).

\subsection{Narrowing Wage Inequality in Recent Reform}

Even though the wage reform mentioned previously improved efficiency and promoted productivity, it also enlarged wage differences and contributed to the growth overall income inequality. As noted by Brandt et al. (2014), China's income inequality, calculated with data from national household surveys, increased from 0.18 in 1978 to over 0.5 in 2012. And, a calculation by Knight and Song (2003) indicated that wage inequality between individuals made the largest contribution by about $45 \%$.

The widened and rising wage disparity may arouse social conflicts because an increasing number of employees may believe they are unfairly treated in wage distribution. In order to prevent social unrest and maintain social justice, the Chinese government has reemphasized the importance of equity in wage distribution since 2000. For example, in 2002, at the 16th National Congress of CCP, the government stated that common prosperity is a goal of national development. The new round of wage reform should aim to increase the proportion of middle-income earners, and improve the incomes of poor people.

In 2007, at the 17th National Congress of the Communist Party of China, the then president HU Jintao stressed in his keynote speech:

'We will increase transfer payments, intensify the regulation of incomes through taxation, break business monopolies, create equal opportunities, and overhaul income distribution practices with a view to gradually reversing the growing income disparity ...'(Feng, 2007)

In November 2013, at the 18th CCP National Congress (Beijing), the current Chinese president XI Jinping once again emphasized the importance of reducing wage/income inequality through a deepening reform of the Chinese current wage system. He pointed out:

\footnotetext{
"A proper balance should be struck between efficiency and fairness (equity) in both primary and secondary wage distribution, with particular emphasis on fairness in the redistribution ..." (Huang, 2012)
} 
As highlighted in the excerpt, this is the first indication that equity receives more attention than efficiency in wage distribution after the wage reform in 1978.

To narrow wage inequality between the rich and the poor, the Chinese government made efforts in three aspects. First was lowering wages of high wage earners. Considering the fact that workers in state-owned large-size enterprises earned higher wages than those in others, the government restored the "profit-delivering" system in 2007 and required the state-owned large firms to hand in a proportion of profits. This initiative aims to reduce the amount of profits that state-owned enterprises could used to raise workers' wages. The delivering profit ratio varies according to types of enterprises. China Tobacco Corporation is required to hand in the highest ratio of profit with a percentage of $20 \%$ (Note 3 ). According to the Chinese government regulation, the delivering profit ratio will raise to $30 \%$ by 2020 . Thus, the government could have more money to protect poor people and maintain social stability. Second was reducing and finally eliminating civil servants' "hidden income (or grey income)", which refers to nonofficial payments, such as banquets, shopping cards, merchandises, and money. The grey income was assumed the major cause for an enlarged wage gaps between civil servants and others (Brandt et al., 2014). The last one was increasing low-income earners' disposable income. Since 2005, the government raised the tax threshold of personal income three times: first from 800 RMB Yuan in 1980 to 1600 RMB in 2005, and then to 2000 RMB Yuan in 2008 and finally to 3500 RMB Yuan in 2011. In 2006, the government cancelled agricultural taxes nationwide to reduce farmers' financial burden and increase their disposable income.

\section{The impact of Wage Reform on Wage Distribution}

\subsection{Wage Increase}

A major motivation of wage reform in China is to increase people's living standards through increasing wages. Apparently, this goal has been achieved. As illustrated by Figure 2, over the last three decades, the annual average wage of national employment increased significantly from 1978 to 2011. For example, the real annual wage of workers, as depicted by the black solid line in Figure 2, was only 615 Chinese Yuan in 1978. By 2011, the average annual real wage of employees raised to 6888 Chinese Yuan, which is over tenfold of that in 1978. In addition, the wage growth is in consistent with the pace of trade reform. As is shown in the read dotted line in Figure 2, the wage growth was relatively slow in the whole 1980s and most years of 1990s when wage reform was moderate, with an average annual wage growth rate only 3.34\% betwwn 1978 and 1997. Starting from 1998, the wage growth has accelerated, with an average annual growth rate of over 10\% between 1998 and 2011.

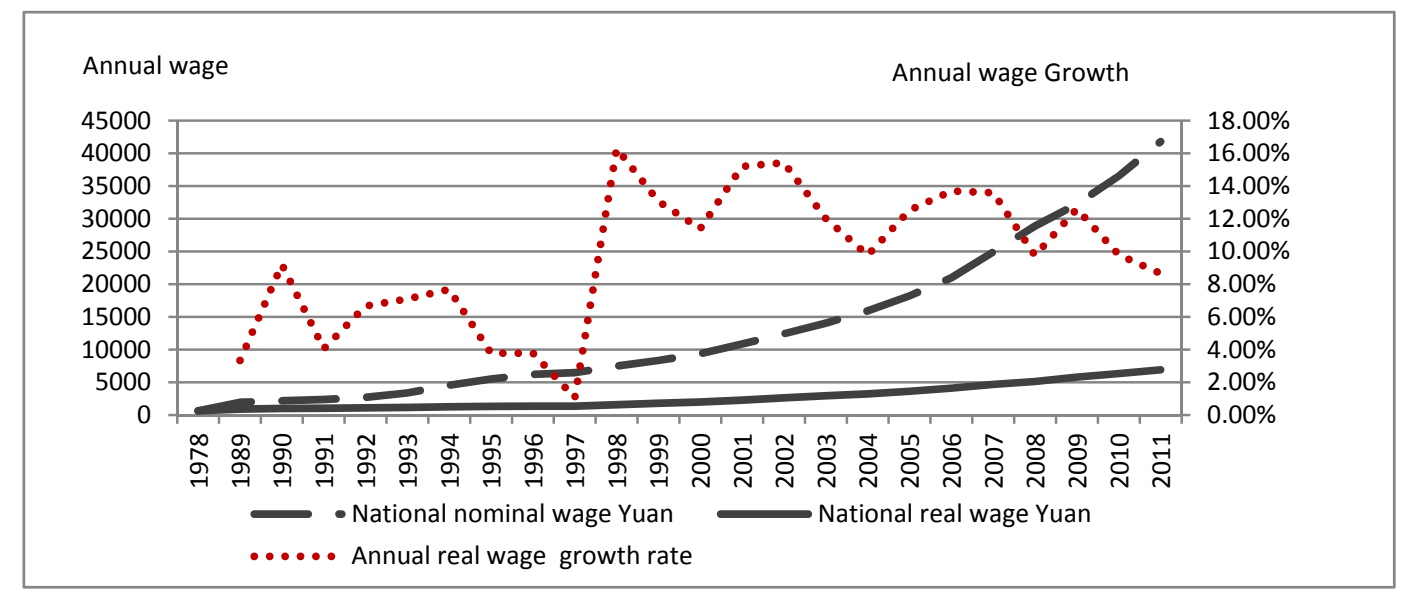

Figure 2. Real annual wages of staff and workers by ownership type, 1978-2011

Source: Chinese Labor Yearbooks, various editions from 1993 to 2012

Notes: The real wages are calculated by deflating the nominal wage by national CPI index $(1978=100)$

To test whether the fruits of rising wage are equally shared proportionately across different income groups, this study employs the $\beta$ convergence and regresses wage growth on the initiative level of wage using the ordinary least square method. The regression model is:

$$
\log \left(\Delta w_{i t}\right)=\alpha+\beta \log \left(w_{i t-1}\right)+\mu_{i t}
$$


Where $\log \left(\Delta w_{i t}\right)$ is the logarithm value of the rate of wage growth in province $i$ at year $t . \log \left(\Delta w_{i t-1}\right)$ the logarithm value of wage level in province $i$ at year $t-1 . u_{i t}$ is the standard error term. $\alpha$ is the constant term, and $\beta$ is the beta convergence parameter of interest.

The estimated result of equation (1) is presented below in Table 2 . The estimated $\beta$ is 0.028 at $1 \%$ level of significance, indicating that wages of 31 Chinese provinces diverged at a rate of $2.8 \%$ for the whole period from 1992 to 2010. It also means that provinces with higher wages in the previous years has higher growth rate. In other words, the rich provinces are becoming richer while the poor are becoming poorer between 1992 and 2010.

Table 2. $\beta$-convergence estimation results

\begin{tabular}{lllll}
\hline Time Period & Constant & $\beta$ & Adjusted R2 & F-statistic \\
\hline $1992-2010$ & $-0.143^{* * *}$ & $0.028^{* * *}$ & 0.065 & 39.49 \\
& $(0.038)$ & $(0.004)$ & & $(\mathrm{p}: 0.000)$ \\
\hline
\end{tabular}

Notes: Standard errors are in parenthesis.

\subsection{Enlarged Wage Inequality between SOEs and Non-SOES}

However, along with wage growth, wage inequality has also widened. For example, the wage gap between workers in SOEs and those in non-stated owned enterprises has enlarged. As illustrated by Figure 3, between 1978 and 2011, the wage ratio between SOEs and TVEs had increased from 1.32 to 1.51 and the wage gap between SOEs and other ownership firms had enlarged from 0.76 to 1.05 . One reason for this phenomenon is that most of state-owned enterprises in China are in monopolized industries, such as petrol, electricity, bank service etc. Thus, as noted by Zhao (2002), employees working in SOEs earned significantly higher salaries than those in other types of enterprises. This wage gap between SOEs and the rest could be even higher when the value of non-wage benefits, such as pension, house, and health care, is included.

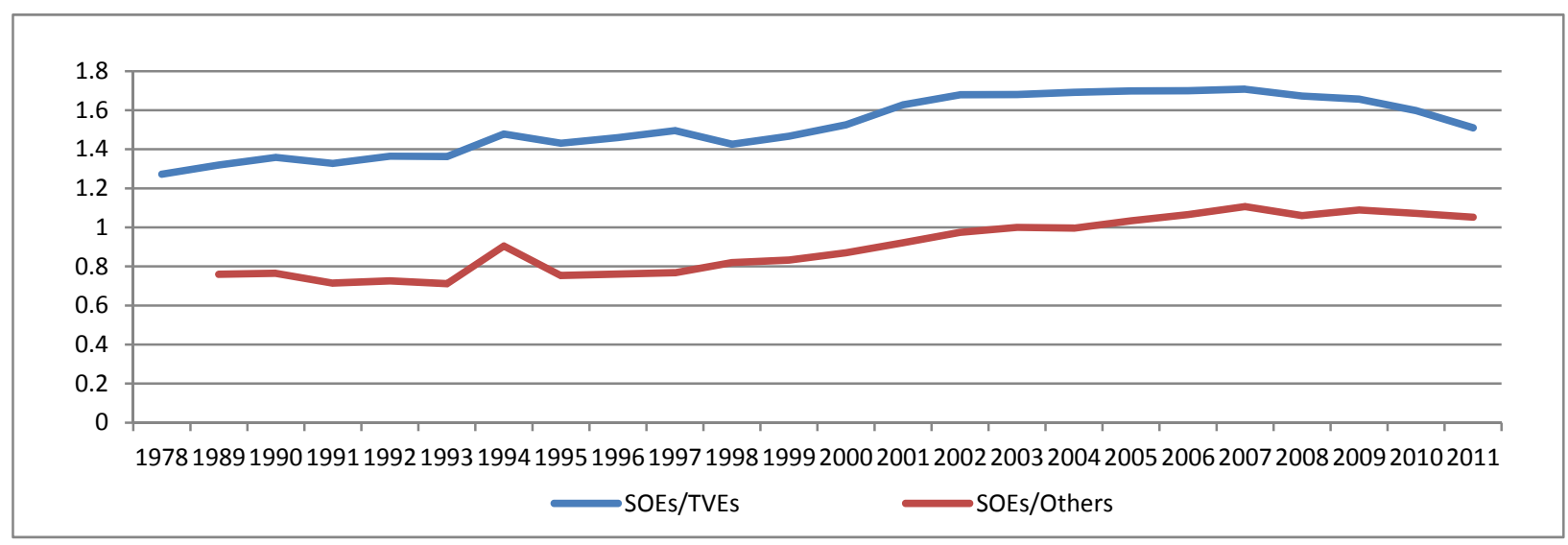

Figure 3. Wage ratios by ownership type, 1978-2011 (Yuan in 1978 price)

Source: Chinese Labor Yearbooks, various editions from 1993 to 2012

\subsection{Wage Inequality across Provinces and Industries}

Apart from growing wage inequality across firms in different ownerships discussed in the previous part, wage inequalities across regions and across industries have also increased since 1978. Using two standard inequality measures, the GINI coefficient (GINI) and coefficient of variation (CV), Table 3 presents the wage inequality across industries and across regions in specific years between 1978 and 2010. Overall, both regional and industrial wage variations have increased persistently and significantly in the past three more decades. The provincial wage inequality (measured as Gini coefficient) increased by 50\% from 8.6 to 12.6 between 1978 and 2010 , and the wage inequality across industries rose from 10.3 to 18.36 during the same period. 
Table 3. Wage inequality across provinces and across industries between 1978 and 2010

\begin{tabular}{ccccc}
\hline \multirow{2}{*}{ Year } & \multicolumn{2}{c}{ Provinces } & \multicolumn{3}{c}{ Industries } \\
\cline { 2 - 5 } & GINI & CV & GINI & CV \\
\hline Panel A: Wage inequality across provinces or across industries (\%) & & 18.1 \\
1978 & 8.6 & 16.3 & 10.3 & 17.2 \\
1980 & 7.5 & 14.6 & 9.7 & 15.2 \\
1985 & 9.1 & 18.1 & 8.8 & 13.6 \\
1990 & 9.3 & 17.6 & 7.7 & 19.6 \\
1995 & 12.3 & 24.5 & 11.2 & 23.8 \\
2000 & 14.2 & 28.5 & 13.9 & 35.3 \\
2005 & 13.8 & 29.4 & 19.1 & 33.69 \\
2010 & 12.58 & 26.26 & 18.36 & \\
Panel B: Annual growth rate in wage inequality (\%) & & & -2.46 \\
$78-85$ & 0.81 & 1.51 & -2.22 & -0.72 \\
$86-90$ & 1.39 & 0.58 & -1.26 & 8.58 \\
$91-95$ & 7.53 & 9.25 & 8.44 & 4.06 \\
$96-00$ & 2.63 & 2.52 & 4.40 & 8.58 \\
$01-05$ & -1.57 & 0.26 & 6.40 & -1.51 \\
$06-10$ & -2.64 & -3.43 & -1.62 &
\end{tabular}

Source: The author calculated using the average wage data for industries and for provinces from Chinese Labor Statistic Yearbook, various editions.

Panel B of Table 3 shows annual growth rates of wage inequality across provinces and industries in six short periods. It shows that the period 1991-1995 witnessed the fastest growth in both regional and industrial wage inequalities. In this period, the annual growth rate of wage inequality (the Gini coefficient) was 7.53 across provinces and 8.44 across industries. Starting from 2000, the growth of wage inequality slowed down. In 2005-2010, both wage inequalities across provinces and industries experienced negative growth. Take Gini coefficient as an example, the provincial wage inequality declined by $2.64 \%$ annually, and the industrial wage inequality by $1.62 \%$. The finding of decreasing wage inequality in late $2000 \mathrm{~s}$ is in accordance with the implementation of new wage reform in this period, which aimed to reduce wage inequality and maintain social justice.

\section{Conclusion}

This paper has presented evidence of the tension between efficiency and equity in the determination of wages. We have drawn upon the recent history of China's wage reform where we have examined the impacts of these reforms on wage distribution. The analysis reveals that wage distribution has widened with reforms, thus the increased efficiency from the reforms have been to the cost of equity in income across the population of workers.

Equity was central to the considerations of a socialist state when first created in 1949. Up until 1978, China was dominated by the ideology of egalitarianism, and thus although the wage level was low, the inequality in wages paid to workers was considerably small. In 1978, as an intergral part of economic reform, China's wage system was transformed from the planned wage system to market-oriented one. Therefore, efficiency replaced equity and became the main principle of wage distribution, and wage equalitarianism was broken. As a result, workers' wages as well as wage inequality have both increased. The enlarged and rising wage inequality becomes a potential threat to social stability. Thus, in 2000 s, the latest three generations of Chinese leadership put more emphasis on equity than efficiency when making wage policy.

This study shows that, although efficiency and equity are most important objectives for each country, it is hard to achieve both together. The government faces a trade-off between them parallel to economic development, proverty reduction as well as social stability. The experience of China's wage reform is a good example that illustrates the importance of balancing efficiency and equity in the determination of a wage policy. Too much 
emphasis on equity, as China did before 1978, led to a common poverty and hindered economic progress. Too much emphasis on efficiency, on the contrary, widened wage inequality as China has experienced over the last three decades. Thus, this study provides valuable empirical evidence of trade-offs between efficiency and equity that other developing countries can refer.

\section{Acknowledgments}

The authors are grateful to the anonymous reviewer and the editor for their constructive comments and valuable suggestions. We thank Dr. Maria Schroder and Dr. Maya Gunawardena for their assistances in manuscript preparation.

\section{References}

Arrow, K. J., Chenery, H. B., Minhas, B. S., \& Solow, R. M. (1961). Capital-labor substitution and economic efficiency. The Review of Economics and Statistics, 225-250. http://dx.doi.org/10.2307/1927286

World Bank. (2010). Results Profile: China Poverty Reduction. Retrieved from http://www.worldbank.org/en/news/feature/2010/03/19/results-profile-china-poverty-reduction.

Brandt, L., Ma, D., \& Rawski, T. G. (2014). From Divergence to Convergence: Reevaluating the History behind China's Economic Boom. Journal of Economic Literature, 52(1), 45-123. $\mathrm{http}: / / \mathrm{dx}$. doi.org/10.1257/jel.52.1.45

Deng, S., Li, M., Wu, L., \& Su, J. (2013). Bian Ge Feng Sheng (1980-1989) (Major events in China's history): Green Apple Data Center.

Fang, C. (2010). Labor Market Development and Expansion of Rural and Urban Employment. In F. Cai (Ed.), Transforming the Chinese Economy (pp. 85-114). Leiden and Boston: Brill. http://dx.doi.org/10.1163/ej.9789004184213.i-354.25

Feng, T. (2007, 15 October, 2007). Hu Jintao vows to "reverse growing income disparity" Xinhua News.

Hicks, J. R. (1955). Economic foundations of wage policy. The Economic Journal, 389-404. http://dx.doi.org/10.2307/2227316

Huang, J. (2012). Full text of Hu Jintao's report at 18th Party Congress, Xinhua News. Retrieved from http://news.xinhuanet.com/english/special/18cpcnc/2012-11/17/c_131981259.htm

Jia, L. (1998). Discussion on the reform of state-owned enterprise salary system. Journal of Nanjing University(4).

Knight, J., \& Song, L. (2003). Increasing urban wage inequality in China. Economics of Transition, 11(4), 597-619. http://dx.doi.org/10.1111/j.0967-0750.2003.00168.x

Li, S., \& Zhao, R. W. (1998). The Changes in Income distribution that have Taken Place since China's Economic Reform Began. Management World, 1, 43-56.

Ma, L. J. (2002). Urban transformation in China, 1949-2000: a review and research agenda. Environment and planning A, 34(9), 1545-1570. http://dx.doi.org/10.1068/a34192

Ru, X., Lu, X., \& Li, P. (2006). Analysis and Forecast on China's Social Development (2006). Beijing: Social Sciences Academic Press.

Samuelson, P. A., \& Nordhaus, W. D. (2001). Microeconomics, 17. Aufl., Boston ua.

Song, Y. (2009). In K.-y. Law \& Y. Zheng (Eds.), Changed and unchanged: thirty years of reform in China (pp. 293-301). Hong Kong: Hong Kong City University Press.

Sun, L. T., Zhang, S. Y., \& Ge, M. H. (1989). Prospects of Chinese wage reform: a synergy of market and planning systems. International Journal of Social Economics, 8, 26-34. http://dx.doi.org/10.1108/03068298910133115

Yang, K. s. (2007). From Provision of Goods to a Wage Hierarchy based on Rank: Changes in the Income Distribution System for Party and Government Off icials at the Time of the Establ ishment of the Peopleps Republ ic of China. Historical Research, 4, 125-129.

Zhao, Y. (2002). Earnings Differentials between State and Non - State Enterprises in Urban China. Pacific Economic Review, 7(1), 181-197. http://dx.doi.org/10.1111/1468-0106.00010

Zhu, C. J., De Cieri, H., \& Dowling, P. J. (1998). The reform of employee compensation in China's industrial enterprises. MIR: Management International Review, 65-87. 


\section{Notes}

Note 1. Shan Ganning district was the header quarter for the Chinese Communist Party in the wartime between 1943 and 1949.

Note 2. In January of 1985, the CCP central committee enacted a notice about the wage reform for state-owned enterprises, which documented that: "since the year of 1985, for all of large and medium-size enterprises, employees' total wage should fluctuate with firms' economic performance".

Note 3. In 2012, the Chinese government divided state-owned enterprises into five categories according to profit ratio delivered to the government: resource monopolies (profit delivering ratio is 15\%), competitive enterprises (profit delivering ratio is $10 \%$ ), special enterprises including military industrial enterprises and China Post Group Corporation (profit delivering ratio is 5\%), the policy company such as China grain reserves corporation (profit delivering ratio is $0 \%$ ), and China Tobacco Corporation (profit delivering ratio is $20 \%$ ).

\section{Copyrights}

Copyright for this article is retained by the author(s), with first publication rights granted to the journal.

This is an open-access article distributed under the terms and conditions of the Creative Commons Attribution license (http://creativecommons.org/licenses/by/3.0/). 